\title{
The cost-effectiveness of treating chronic hepatitis B patients in a median endemic and middle income country
}

\author{
Mehlika Toy • Fatih Oguz Onder • Ramazan Idilman · Gokhan Kabacam • \\ Jan Hendrik Richardus • Mithat Bozdayi • Meral Akdogan · Zarife Kuloglu • \\ Aydan Kansu • Solko Schalm • Cihan Yurdaydin
}

Received: 23 October 2011 / Accepted: 19 June 2012/Published online: 20 July 2012

(C) The Author(s) 2012. This article is published with open access at Springerlink.com

\begin{abstract}
Background/aims Chronic hepatitis B (CHB) infection is a serious public health problem due to its potential liver disease sequelae and highly expensive medical costs such as the need for liver transplantation. The aim of this study was to quantify the burden of active CHB in terms of mortality and morbidity, the eligibility of antiviral
\end{abstract}

Electronic supplementary material The online version of this article (doi:10.1007/s10198-012-0413-8) contains supplementary material, which is available to authorized users.

\footnotetext{
M. Toy $(\bowtie) \cdot$ J. H. Richardus

Department of Public Health, Erasmus MC,

University Medical Center Rotterdam,

Dr. Molewaterplein 50, 3000 CA Rotterdam,

The Netherlands

e-mail: m.toy@erasmusmc.nl

M. Toy $\cdot$ S. Schalm

LiverDoc, Rotterdam, The Netherlands

F. O. Onder · M. Akdogan

Department of Gastroenterology,

Yuksek Ihtisas Hospital, Ankara, Turkey

R. Idilman · G. Kabacam - C. Yurdaydin

Department of Gastroenterology, School of Medicine,

Ankara University, Ankara, Turkey

M. Bozdayi

Hepatology Institute, School of Medicine, Ankara, Turkey

Z. Kuloglu · A. Kansu

Department of Pediatric Gastroenterology and Hepatology,

School of Medicine, Ankara, Turkey

S. Schalm

Department of Gastroenterology and Hepatology,

Erasmus MC, University Medical Center Rotterdam,

Rotterdam, The Netherlands
}

treatment and to assess various treatment scenarios and possible salvage combinations for cost-effectiveness.

Methods A population cohort from a large data base of chronic hepatitis B patients was constructed and stratified according to 10-year age groups, the prevalence of HBsAg, HBV DNA level, ALT level, HBeAg status and the presence of cirrhosis. An age-specific Markov model for disease progression and cost-effectiveness analysis was constructed and calibrated for the specific population setting.

Results Of about 3.2 million estimated HBsAg carriers, $25 \%$ are eligible for treatment. If the active cohort remains untreated, $31 \%$ will die due to liver related complications. Within a 20-year period, $11 \%$ will have developed decompensated cirrhosis, $12 \%$ liver cancer and $6 \%$ will need liver transplantation. Quality adjusted life years (QALYs) for the no treatment scenario ranged from 9.3 to 14.0. For scenarios with antiviral treatment, QALYs ranged from 9.9 to 14.5 for lamivudine, $13.0-17.5$ for salvage therapy, and 16.6-19.0 for the third generation drugs entecavir and tenofovir.

Conclusion In a country with considerable amount of active CHB patients, monotherapy with a highly potent third generation drug has the most health-gain, and is costeffective in both HBeAg-positive and negative in all stages of liver disease.

Keywords Chronic hepatitis B - Cost-effectiveness analysis · Antiviral therapy $\cdot$ Turkey $\cdot$ Middle income

JEL Classification I18

\section{Introduction}

Chronic hepatitis B (CHB) is a major global public health problem and an important cause of morbidity and mortality 
from sequelae related to $\mathrm{CHB}$ which includes cirrhosis development, decompensation and hepatocellular carcinoma [1].

Antiviral therapy is the only option to control and prevent progression of disease in chronic patients. The indications are generally the same for $\mathrm{HBeAg}$-positive and negative patients. These are based mainly on the combination of three criteria: serum HBV DNA and ALT levels, and the stage of liver disease [2].

The course from infection exposure to the development of complications related to $\mathrm{CHB}$ infection may span multiple decades. Once diagnosed, treatment may modify the natural course for the better. The American and European guidelines on treatment of chronic hepatitis $\mathrm{B}$ recommend treatment with pegylated interferon or the nucleos(t)ide analogs (NA) entecavir or tenofovir [2, 3]. The latter two NAs are preferred over other NAs because of their antiviral potency and a high genetic barrier to resistance. However, treatment options need to be balanced in resource constraint settings. It should be of global concern that resource limitations are especially evident where hepatitis B is endemic or hyperendemic such as in the Far East or in SubSaharan Africa [4, 5]. The consequences and costs of treatment strategies may help in contributing to the buildup of health strategies. Based on its GNI (gross national income) per capita, every economy is classified as low income, middle income (subdivided into lower middle and upper middle), or high income, according to the World Bank. The GNI per capita for Turkey is \$9,500, which classifies Turkey as an upper middle income country. To support national health authorities policy making in longterm chronic hepatitis B treatment, we assessed the impact of treatment in preventing adverse outcomes of $\mathrm{CHB}$ infection, and the cost-effectiveness of various treatment strategies. For these goals, Turkey was used and investigated as an example median endemic country.

\section{Methods}

\section{Cohort definition}

A population cohort of $\mathrm{CHB}$ patients was constructed from a recent meta-analysis of age- and region-specific hepatitis B surface antigen (HBsAg) prevalence in Turkey [6]. We projected these age-stratified HBsAg prevalence from the meta-analysis to the total age-specific Turkish population numbers, which was a total of 71.5 million in 2009 [7].

The HBsAg positive cohort was first divided into two groups, active and inactive $\mathrm{CHB}$, based on hepatitis $\mathrm{B}$ e-antigen status, HBV DNA level, and serum alanine aminotransferase (ALT) level. The age-specific distributions of these factors were derived from a newly constructed patient database of the gastroenterology departments of the University of Ankara, and a state hospital in Ankara (Turkiye Yuksek Ihtisas Hastanesi) with 1,453 newly diagnosed CHB patients. Both of these hospital departments receive patients from around the country, which supposedly means that the constructed patient data is heterogeneous. In Turkey, almost all CHB cases are detected at the hospital, of which some patients are coincidentally detected during other medical procedures. The differentiation of active and inactive $\mathrm{CHB}$ is essential since progression of the disease is different in these two groups. Patients with high HBV DNA levels HBV DNA $\geq 10^{4}$ copies $/ \mathrm{mL}$ and elevated $\mathrm{ALT}(>2 \times \mathrm{ULN})$ have potentially progressive liver disease and are candidates for HBV antiviral therapy [2], while those with low or undetectable HBV DNA and normal ALT levels usually are inactive HBsAg carriers with a low risk of disease progression. Lastly, we classified the active $\mathrm{CHB}$ patients into four categories, namely $\mathrm{HBeAg}(+)$ and $\mathrm{HBeAg}(-) \mathrm{CHB}$ with or without cirrhosis, respectively, using age groupspecific proportions from large $\mathrm{HBeAg-positive} \mathrm{and}$ HBeAg-negative clinical trials [8, 9].

Model and clinical probability estimates

We evaluated the cohort of treatment-naïve active CHB patients for mortality, morbidity, impact of treatment and cost-effectiveness of various treatment strategies for a follow-up time of 20 years, thus the cycle length was 21 , and the half cycle correction was applied with the TreeAge Pro 2009 software (TreeAge Software, Inc., MA, USA). The model uses annual probabilities of transition from $\mathrm{CHB}$ to virologic response, and of progression to cirrhosis, decompensated liver disease or hepatocellular carcinoma, liver transplantation, and finally death. The natural history and treatment related annual probabilities are obtained mostly from systematic reviews (Tables 1, 2) [10-36]. Other causes of death not related to liver disease are included in the model, as age-specific mortality rates derived from the Turkish statistics institute [7]. The probabilities of receiving a liver transplant were calculated based on personal communications with six major liver transplantation centres distributed throughout Turkey. We received reports that included annual numbers of liver transplants due to $\mathrm{HBV}$ related decompensated cirrhosis and HCC. From these figures, we calculated that there are annually around 500 liver transplantations performed in Turkey, of which about 150 are for HBV alone (no coinfections included). Out of these 150 liver transplantations, 120 are due to decompensated cirrhosis, and 30 to HCC. This corresponds to an annual probability of receiving a liver transplant for decompensated cirrhosis of 24 and $6 \%$ for HCC. 
Scenario analysis

The following treatment options used by clinicians in Turkey were analyzed:

Natural History (no antiviral treatment) scenario: In this scenario, which is the base case scenario, active CHB patients progress according to the natural history, following annual rates of progression derived from systematic reviews (Table 1). Since the disease progression rates differ among European and Asian cohort studies [11], we only implemented in the model the annual progression rates derived from European cohort studies. We assumed that patients were followed clinically but did not receive antiviral therapy for CHB. Patients followed the natural history according to their HBeAg and disease status (with or without cirrhosis). Resolution was defined as seroconversion to anti-HBe in $\mathrm{HBeAg}$ positive patients, and as persistent HBV DNA suppression and ALT normalization in $\mathrm{HBeAg}$ negative patients. We assumed that all patients received regular ongoing care once complications occur.

Lamivudine monotherapy scenario: In this scenario, patients received $100 \mathrm{mg}$ orally once daily with the first licensed antiviral HBV drug that is associated with a high incidence of resistance [24]. Such monotherapy is still being practiced in many countries with limited resources $[5,37]$. We defined sustained virological response (SVR) in $\mathrm{HBeAg}$ positive patients as HBe-antigen loss and development of antibodies against $\mathrm{HBeAg}$ (anti-HBe).
Entecavir monotherapy scenario: Patients in this strategy received $0.5 \mathrm{mg}$ entacavir once daily [38, 39]. The treatment related probability estimates are shown in Table 2.

Tenofovir monotherapy scenario: In this scenario patients received $300 \mathrm{mg}$ of tenofovir for a continuum of 20 years. The annual probability of resistance in this scenario was $0 \%$ for the first and second years of treatment.

Adefovir salvage scenario: In this scenario, patients initially receive lamivudine. Once resistance occurs, patients are salvaged add-on by add-on adefovir. Patients without resistance continued to receive lamivudine.

Tenofovir salvage scenario: In this more up-to-date scenario, patients who have developed resistance during lamivudine therapy are switched to treatment with tenofovir [31].

Pegylated Interferon, followed by tenofovir scenario: In this scenario patients receive $180 \mathrm{mcg} / \mathrm{mL}$ of pegylated interferon once a week subcutaneously, for 48 weeks. If the patients do not respond or relapse, they start tenofovir in the following year. The annual transition rates for SVR after 72 weeks of Peg-IFN was $30 \%$ for HBeAg-positive and $20 \%$ for $\mathrm{HBeAg-negative} \mathrm{patients} \mathrm{[32-34,} \mathrm{40].} \mathrm{The}$ withdrawal rate was 2 and $5 \%$ for $\mathrm{HBeAg}$-positive and negative patients, respectively [35].

Roadmap concept scenario: In this scenario we applied the 'roadmap concept' [41] to the sub-group of CHB noncirrhotic $\mathrm{HBeAg}$-negative cases treated with lamivudine, due to its low price, which continues to be widely used in HBV endemic areas. Patients with HBV DNA levels $<10^{7}$ copies/mL start therapy with lamivudine; after
Table 1 Annual transition estimates of the natural history of chronic hepatitis B by initial state

\begin{tabular}{llll}
\hline Initial state & Outcome & Estimate $(\%)^{*}$ & References $^{\mathrm{a}}$ \\
\hline Chronic hepatitis B e+ & Resolution & $6.9(2.0-23)$ & {$[10]$} \\
& Cirrhosis & $3.8(1.6-5.9)$ & {$[11]$} \\
& Hepatocellular carcinoma & $0.3(0.3-0.6)$ & {$[11]$} \\
Chronic hepatitis B e- & Chronic hepatitis B e- & $1.9(1.0-3.8)$ & {$[11]$} \\
& Resolution & $1.6(0.0-11)$ & {$[10]$} \\
Cirrhosis e+ & Cirrhosis & $9.7(2.9-16.3)$ & {$[11]$} \\
& Hepatocellular carcinoma & $0.3(0.3-0.6)$ & {$[11]$} \\
Cirrhosis e- & Decompensated cirrhosis & $3.9(2.0-7.9)$ & {$[12-14]$} \\
& Hepatocellular cancer & $1.8(0.9-3.8)$ & {$[12-14]$} \\
& HBV related death & $3.1(3.1-3.8)$ & {$[12-14]$} \\
Decompensated Cirrhosis & Decompensated cirrhosis & $2.7(1.4-5.4)$ & {$[12-14]$} \\
& Hepatocellular cancer & $2.9(1.0-5.6)$ & {$[12-14]$} \\
& HBV related death & $3.1(3.1-3.8)$ & {$[12-14]$} \\
& Liver transplantation & $23(15-25)$ & Personal \\
Hepatocellular carcinoma & HBV related death & $26(15-62)$ & {$[12-14]$} \\
& Liver transplantation & $6(3.0-7.0)$ & Personal \\
& & & communication \\
& HBV related death & $35(20-60)$ & {$[10]$} \\
& HBV related death & $6.6(2.0-12)$ & {$[10]$} \\
\hline
\end{tabular}


Table 2 Treatment-related annual transition estimates

\begin{tabular}{|c|c|c|c|c|c|c|c|c|c|c|c|}
\hline \multirow{3}{*}{$\begin{array}{l}\text { Initial state } \\
\mathrm{HBeAg} \text { status }\end{array}$} & \multirow[t]{3}{*}{ Outcome } & \multicolumn{10}{|c|}{ Estimate $(\%)$} \\
\hline & & \multicolumn{2}{|c|}{ Lamivudine } & \multicolumn{2}{|c|}{ Entecavir $^{\mathrm{h}}$} & \multicolumn{2}{|c|}{ Adefovir salvage } & \multicolumn{2}{|c|}{ Tenofovir $^{\mathrm{i}}$} & \multicolumn{2}{|c|}{ Tenofovir salvage } \\
\hline & & + & - & + & - & + & - & + & - & + & - \\
\hline \multirow[t]{3}{*}{ CHB initial therapy ${ }^{a}$} & Sustained virological response & 20 & 10 & $22^{b}$ & $11^{\mathrm{b}}$ & 12 & 10 & 23 & 11 & 19 & 11 \\
\hline & Cirrhosis $^{c}$ & 0.5 & 1.2 & 0.2 & 0.6 & 0.5 & 1.2 & 0.2 & 0.6 & 0.5 & 1.2 \\
\hline & Hepatocellular carcinoma ${ }^{\mathrm{f}}$ & 0.2 & 0.2 & 0.2 & 0.2 & 0.2 & 0.2 & 0.2 & 0.2 & 0.2 & 0.2 \\
\hline \multirow[t]{8}{*}{ CHB long-term therapy } & Sustained virological response & 24 & 10 & $27^{\mathrm{b}}$ & $11^{\mathrm{b}}$ & 12 & 10 & 27 & 11 & 19 & 11 \\
\hline & Cirrhosis ${ }^{c}$ & 0.5 & 1.2 & 0.2 & 0.6 & 0.5 & 1.2 & 0.2 & 0.6 & 0.5 & 1.2 \\
\hline & Resistance: year 1 & $23^{\mathrm{d}}$ & $23 \mathrm{e}$ & 0.1 & 0.1 & $6^{\mathrm{e}}$ & $6^{\mathrm{e}}$ & 0 & 0 & 0 & 0 \\
\hline & Year 2 & $42^{d}$ & $42^{d}$ & 0.3 & 0.3 & $21^{\mathrm{e}}$ & $21^{\mathrm{e}}$ & 0 & 0 & 1 & 1 \\
\hline & Year 3 & $53^{d}$ & $53^{d}$ & 0.4 & 0.4 & $21^{\mathrm{e}}$ & $21^{\mathrm{e}}$ & 0.4 & 0.4 & 1 & 1 \\
\hline & Year 4 & $70^{\mathrm{d}}$ & $70^{\mathrm{d}}$ & 0.8 & 0.8 & $21^{\mathrm{e}}$ & $21^{\mathrm{e}}$ & 0.8 & 0.8 & 1 & 1 \\
\hline & Year 5 & $74^{\mathrm{d}}$ & $74^{\mathrm{d}}$ & 1 & 1 & $21^{\mathrm{e}}$ & $21^{\mathrm{e}}$ & 1 & 1 & 1 & 1 \\
\hline & Hepatocellular carcinoma ${ }^{\mathrm{f}}$ & 0.2 & 0.2 & 0.2 & 0.2 & 0.2 & 0.2 & 0.2 & 0.2 & 0.2 & 0.2 \\
\hline \multirow[t]{3}{*}{ Resistant CHB long-term therapy } & Sustained virological response & 4.5 & 0 & $5^{\mathrm{b}}$ & $0.5^{\mathrm{b}}$ & 4.5 & 0 & 5 & 0.5 & 5 & 0.5 \\
\hline & Cirrhosis $^{c}$ & 2.7 & 6.2 & 2.7 & 6.2 & 2.7 & 6.2 & 2.7 & 6.2 & 2.7 & 6.2 \\
\hline & Hepatocellular carcinoma ${ }^{\mathrm{f}}$ & 0.4 & 0.4 & 0.4 & 0.4 & 0.4 & 0.4 & 0.4 & 0.4 & 0.4 & 0.4 \\
\hline \multirow[t]{2}{*}{ Cirrhosis initial therapy } & Sustained virological response & 20 & 10 & $22^{b}$ & $11^{\mathrm{b}}$ & 12 & 10 & 23 & 12 & 19 & 11 \\
\hline & Hepatocellular carcinoma $^{\mathrm{f}}$ & 0.9 & 1.5 & 0.9 & 1.5 & 0.9 & 1.5 & 0.9 & 1.5 & 0.9 & 1.5 \\
\hline \multirow[t]{9}{*}{ Cirrhosis long-term therapy } & Sustained virological response & 24 & 10 & $27^{\mathrm{b}}$ & $11^{\mathrm{b}}$ & 12 & 10 & 27 & 11 & 19 & 11 \\
\hline & Resistance: year 1 & $23^{\mathrm{d}}$ & $23^{d}$ & 0.1 & 0.1 & $6^{\prime \prime}$ & $6^{\prime \prime}$ & 0 & 0 & 0 & 0 \\
\hline & Year 2 & $42^{d}$ & $42^{d}$ & 0.3 & 0.3 & $21^{\mathrm{e}}$ & $21^{\mathrm{e}}$ & 0 & 0 & 1 & 1 \\
\hline & Year 3 & $53^{\mathrm{d}}$ & $53^{\mathrm{d}}$ & 0.4 & 0.4 & $21^{\mathrm{e}}$ & $21^{\mathrm{e}}$ & 0.4 & 0.4 & 1 & 1 \\
\hline & Year 4 & $70^{\mathrm{d}}$ & $70^{\mathrm{d}}$ & 0.8 & 0.8 & $21^{\mathrm{e}}$ & $21^{\mathrm{e}}$ & 0.8 & 0.8 & 1 & 1 \\
\hline & Year 5 & $74^{\mathrm{d}}$ & $74^{\mathrm{d}}$ & 1 & 1 & $21^{\mathrm{e}}$ & $21^{\mathrm{e}}$ & 1 & 1 & 1 & 1 \\
\hline & Decompensated cirrhosis & 1.9 & 1.9 & 1.9 & 1.9 & 1.9 & 1.9 & 1.9 & 1.9 & 1.9 & 1.9 \\
\hline & Hepatocellular carcinoma & 1.6 & 1.6 & 1.6 & 1.6 & 1.6 & 1.6 & 1.6 & 1.6 & 1.6 & 1.6 \\
\hline & Death HBV & 2.4 & 2.4 & 2.4 & 2.4 & 2.4 & 2.4 & 2.4 & 2.4 & 2.4 & 2.4 \\
\hline \multirow[t]{4}{*}{ Resistant cirrhosis long-term therapy } & Sustained virological response & 4.5 & 0 & $5^{\mathrm{b}}$ & $0.5^{\mathrm{b}}$ & 4.5 & 0 & 5 & 0.5 & 5 & 0.5 \\
\hline & Decompensated Cirrhosis & 7.9 & 7.9 & 7.9 & 7.9 & 7.9 & 7.9 & 7.9 & 7.9 & 7.9 & 7.9 \\
\hline & Hepatocellular carcinoma & 1.8 & 2.9 & 1.8 & 2.9 & 1.8 & 2.9 & 1.8 & 2.9 & 1.8 & 2.9 \\
\hline & Death HBV & 3.1 & 3.1 & 3.1 & 3.1 & 3.1 & 3.1 & 3.1 & 3.1 & 3.1 & 3.1 \\
\hline \multirow[t]{2}{*}{ Decompensated Cirrhosis } & Liver transplantation $^{\mathrm{g}}$ & 3.3 & 3.3 & 3.3 & 3.3 & 3.3 & 3.3 & 3.3 & 3.3 & 3.3 & 3.3 \\
\hline & Death HBV & 26 & 26 & 26 & 26 & 26 & 26 & 26 & 26 & 26 & 26 \\
\hline \multirow[t]{2}{*}{ Hepatocellular carcinoma } & Liver transplantation $^{\mathrm{g}}$ & 1.2 & 1.2 & 1.2 & 1.2 & 1.2 & 1.2 & 1.2 & 1.2 & 1.2 & 1.2 \\
\hline & Death HBV & 35 & 35 & 35 & 35 & 35 & 35 & 35 & 35 & 35 & 35 \\
\hline Liver transplantation & Death HBV & 6.6 & 6.6 & 6.6 & 6.6 & 6.6 & 6.6 & 6.6 & 6.6 & 6.6 & 6.6 \\
\hline
\end{tabular}

Estimates from Kanwal et al. [10, 15]

a Initial therapy is 12 months (48 weeks) of therapy

b Estimates from recent clinical trials: Chang et al. [16], Lai et al. [17] and Colonno et al. [18]

c Estimates calculated by the author, based on the assumption that the natural progression rates of chronic hepatitis B are reduced by antiviral therapy. Estimates derived from natural history estimate similar to Kanwal's assumption of no progression of disease in HBeAg seroconversion, we assume no progression of disease in case HBV DNA is undetectable by PCR. In the papers from Chang and Lai full suppression of HBV DNA was observed in $80 \%$ with a high resistance profile drug, and $90 \%$ with a low resistance profile drug. We took these percentages for our calculations. Refs. [16, 17]

d Estimates for Lamivudine resistance from Lai et al. [19] and Moskovitz et al. [20]

e Adefovir salvage resistance estimates from Lee et al. [21], Chen et al. [22] and Yeon et al. [23]

${ }^{f}$ Estimates based on reduction of progression rates by nucleoside analogue therapy of $50 \%$ Ref. [24]

g The probabilities of receiving a liver transplantation for decompensated cirrhosis and hepatocellular carcinoma were calculated on the basis of data from six major transplant centres in Turkey

h Estimates for entecavir resistance from Colonno et al. [18, 25] and Tenney et al. [26]

i Tenofovir monotherapy estimates Ref. [27]

j Tenofovir salvage scenario estimates from van Bommel et al. [28], Sarin et al. [29], van Bommel et al. [30] and Reijnders et al. [31] 
24 weeks virologic response on treatment is assessed. If HBV DNA is undetectable (50 UI/mL, 300 copies $/ \mathrm{mL}$ ), patients continue their treatment with lamivudine until resistance or virologic breakthrough occurs, after which patients are switched to tenofovir. However, if HBV DNA is above 300 copies/mL at 24 weeks, lamivudine is switched to tenefovir monotherapy already at week $24.71 \%$ of patients are expected to become HBV DNA negative at week 24 of treatment [42]. Annual resistance rate in these patients on lamivudine treatment is $2 \%$ [43, 44]. Annual rate of HBV DNA relapse is $8.2 \%$ (28\% at 4 years) [44].

Model assumptions

An assumption was that $\mathrm{HBeAg}$-positive non-cirrhotic patients stop treatment after receiving one year consolidation treatment after $\mathrm{HBeAg}$ seroconversion and achieving undetectable HBV DNA levels [2], while HBeAg-negative patients continue treatment [38] for the follow-up period of 20 years. Also, our model assumes that the resistance for entecavir and tenofovir scenarios stays low as recent studies report. After the third year of treatment tenofovir resistance is assumed to be the same as entecavir. We took different time points to assess the outcomes for pegylated interferon and nucleos(t)ide analogues. For the Peg-IFN scenario we assumed that the non-responders continued with long-term tenofovir treatment both in $\mathrm{HBeAg-positive}$ and negative patients. For the road map concept the annual resistance of $2 \%$ estimate was derived from the GLOBE telbivudine versus lamivudine trial [43].

Cost and utility estimates

Medical costs are obtained from a retrospective analysis of the medical records of a sample of 542 patients $(3,000$ hospital admissions), where a random sample of patients was selected from inactive carriers, CHB active, cirrhosis, HCC and liver transplantation cases. An average annual medical treatment cost (excluding antiviral treatment) per patient in each health state was calculated (unpublished work). Data extracted for outpatient visits included information of visits, diagnosis, type of examination, signs and symptoms, laboratory tests, and procedures. Outpatients costs were mainly costs of laboratory tests, examination and consult. Information for inpatients included the length of stay, bed costs, surgical procedures, radiation treatment and chemotherapy. Annual cost was calculated as: cost per visit $\times$ visit per year + costs per admission $\times$ admission per year. The costs of antiviral drugs are obtained from the Turkish Ministry of Health [45]. A wide range of agespecific health state utilities are obtained from a multinational study on chronic hepatitis B [46]. Table 3 contains

Table 3 Annual costs and health state utilities for chronic hepatitis B

\begin{tabular}{|c|c|c|c|}
\hline Parameter & $\begin{array}{l}\text { Base-case estimate } \\
\text { TL }(€)\end{array}$ & (range) & References \\
\hline \multicolumn{4}{|l|}{ Drug costs (year 2010 values) } \\
\hline Lamivudine treatment $(100 \mathrm{mg})$ & $1,176(585)$ & $884-1,470(439-731)$ & [45] \\
\hline Adefovir salvage treatment $(10 \mathrm{mg})$ & $12,012(5,976)$ & $9,009-15,015(4,482-7,470)$ & [45] \\
\hline Entecavir treatment $(0.5 \mathrm{mg})$ & $11,292(5,618)$ & $8,469-14,115(4,214-7,022)$ & {$[45]$} \\
\hline Tenofovir (300 mg) & $8,028(3,994)$ & $6,021-10,035(2,996-4,992)$ & {$[45]$} \\
\hline Peg-INF alfa 2a (INJVL 180MCG/ML) & $19,344(9,624)$ & $14,508-24,180(7,218-12,030)$ & [45] \\
\hline Medical management costs & & & Personal communication $^{\mathrm{a}}$ \\
\hline Monitoring of $\mathrm{CHB}$ & $720(358)$ & $540-900(269-627)$ & \\
\hline Compensated Cirrhosis & $1,204(602)$ & $903-1,505(452-752)$ & \\
\hline Decompensated Cirrhosis & $5,364(2,668)$ & $4,023-6,705(2,001-3,335)$ & \\
\hline Hepatocellular carcinoma & $14,300(7,114)$ & $10,725-17,875(5,336-8,892)$ & \\
\hline Liver transplantation & $174,050(86,592)$ & $130,538-217,562(64,944-108,240)$ & \\
\hline \multicolumn{4}{|l|}{ Health state utilities ${ }^{\mathrm{b}}$} \\
\hline Durable response to treatment & 1.00 & $(0.95-1.00)$ & [46] \\
\hline Chronic HBV & 0.68 & $(0.66-0.70)$ & {$[46]$} \\
\hline Compensated cirrhosis & 0.69 & $(0.66-0.71)$ & {$[46]$} \\
\hline Decompensated cirrhosis & 0.35 & $(0.32-0.37)$ & {$[46]$} \\
\hline Hepatocellulr carcinoma & 0.38 & $(0.36-0.41)$ & {$[46]$} \\
\hline Liver transplantation & 0.67 & $(0.64-0.69)$ & [46] \\
\hline
\end{tabular}

$C H B$ chronic hepatitis $\mathrm{B}, H B V$ hepatitis $\mathrm{B}$ virus

${ }^{a}$ Obtained from a retrospective analysis of medical records of a sample of 3,000 hospital admissions unpublished work

b See Levy et al. (Ref. [46]) for the age-specific utilities 
the specific cost and utility estimates. All costs and utilities were discounted at a rate of $3 \%$ per year [47].

\section{Outcomes}

By applying the Markov cohort analysis, the cumulative mortality, and the cumulative probability of developing cirrhosis, decompensated cirrhosis, HCC, and getting a liver transplant were quantified for a 20-year time period. We measured costs (2010 Euro and Turkish Lira), quality adjusted life years (QALYs), and the incremental costeffectiveness ratio (ICER), to determine the additional cost to obtain one QALY. The guidelines of economic submission to the BMJ was used for this cost-effectiveness analysis [48].

Sensitivity analysis

To study the effect of uncertainty of the robustness of our results, we performed a sensitivity analysis on the low and high ranges of the transition estimates in the natural history scenario (Table 1). First, a so called best case scenario was assessed by applying the high range of achieving spontaneous virological response, and the low ranges for the estimates of disease progression. Second, a worst case scenario was assessed by applying the low rates for spontaneous virological response, and the high ranges for the disease progression estimates.

We assume that after seroconversion occurs, patients are allowed a 6 month therapy, and NAs are discontinued. A recent publication suggests continuation of long-term nucleos(t)ide analogue treatment, irrespective of the occurrence of $\mathrm{HBeAg}$ seroconversion in $\mathrm{HBeAg}$-positive patients. Following this recent finding, an alternative scenario was assessed where treatment was continued in HBeAg-positive patients.

In addition, we performed a Monte Carlo simulation assuming that all variables followed a triangular distribution, due to its continues distribution, with base case, low and high range of values. We simulated 10,000 trials and plotted the results on cost-effectiveness acceptability curve stratified by cost-effectiveness thresholds to determine which treatment to use under different budgetary restraints.

\section{Results}

Cohort

Table 4 shows the total population of Turkey in 2009 with the age-specific prevalence of HBsAg. Around 3.2 million people ( $4.6 \%$ of the total population) were estimated to be HBsAg carriers, with $22.6 \%$ of them having $\mathrm{HBeAg}$ positive $\mathrm{CHB}$ and $77.4 \%$ having HBeAg-negative CHB. The total number of patients with active CHB was about 828,000 or $25 \%$ of the total HBsAg-positive cohort, of which $57 \%$ had $\mathrm{HBeAg}$-positive and the rest HBeAgnegative $\mathrm{CHB}$. The proportion that had cirrhosis in the active CHB cohort was $13 \%$.

Mortality and morbidity in the active CHB cohort

The estimated age-specific CHB burden in a 20-year follow up is shown in Table 5 for the natural history scenario. If the cohort of 828,347 individuals remains untreated, it is estimated that $256,788(31 \%)$ will die due to liver related complications. Within a 20 -year period, $11 \%$ will have developed decompensated cirrhosis, $12 \% \mathrm{HCC}$ and $6 \%$

Table 4 Age group specific distribution of chronic hepatitis B in Turkey by HBeAg and stage of liver disease

\begin{tabular}{|c|c|c|c|c|c|c|c|c|c|c|}
\hline \multicolumn{2}{|c|}{ Age group } & \multirow[b]{2}{*}{$\mathrm{HBsAg}+(\%)$} & \multirow[b]{2}{*}{$\mathrm{HBeAg}+$} & \multirow[b]{2}{*}{$\mathrm{HBeAg}-$} & \multicolumn{2}{|c|}{ Active $\mathrm{CHB}$} & \multicolumn{2}{|l|}{ Cirrhosis } & \multicolumn{2}{|c|}{$\begin{array}{l}\text { Chronic hepatitis } \\
\text { (no cirrhosis) }\end{array}$} \\
\hline (years) & Population & & & & $\mathrm{HBeAg}+$ & $\mathrm{HBeAg}-$ & $\begin{array}{l}\mathrm{HBeAg}+ \\
(\%)\end{array}$ & $\begin{array}{l}\mathrm{HBeAg}- \\
(\%)\end{array}$ & $\mathrm{HBeAg}+$ & $\mathrm{HBeAg}-$ \\
\hline $0-14$ & $18,788,587$ & $533,596(2.84)$ & 283,828 & 249,768 & 90,621 & 47,586 & 1,818 & $2,379(5)$ & 88,808 & 45,207 \\
\hline $15-24$ & $12,441,662$ & $490,201(3.94)$ & 176,473 & 313,729 & 91,504 & 45,804 & $1,830(2)$ & $2,290(5)$ & 89,674 & 43,514 \\
\hline $25-34$ & $12,328,944$ & $784,121(6.36)$ & 159,961 & 624,160 & 113,892 & 132,322 & $6,834(6)$ & $9,263(7)$ & 107,058 & 123,059 \\
\hline $35-44$ & $10,070,734$ & $624,386(6.20)$ & 62,439 & 561,947 & 35,222 & 96,610 & $2,466(7)$ & $14,491(15)$ & 32,756 & 82,118 \\
\hline $45-54$ & $7,927,348$ & $437,590(5.52)$ & 22,655 & 414,935 & 11,923 & 74,353 & $2,981(25)$ & $20,819(28)$ & 8,943 & 53,534 \\
\hline $55-64$ & $5,066,402$ & $184,924(3.65)$ & 12,753 & 172,170 & 5,070 & 41,595 & $1,673(33)$ & $21,214(51)$ & 3,397 & 20,382 \\
\hline $65+$ & $4,893,423$ & $197,205(4.03)$ & 18,260 & 178,945 & 4,565 & 37,280 & 0 & 20,877 (56) & 4,565 & 16,403 \\
\hline Total & $71,517,100$ & $3,252,022(4.57)$ & 736,367 & $2,515,655$ & 352,797 & 475,550 & $17,595(9)$ & 91,333 (19) & 335,202 & 384,217 \\
\hline
\end{tabular}

$C H B$ chronic hepatitis $\mathrm{B}, H B e A g$ hepatitis $\mathrm{B}$ e antigen, $H B s A g$ hepatitis $\mathrm{B}$ surface antigen 
Table 5 Age-specific clinical outcome of active chronic hepatitis B by HBeAg status in the natural history scenario

\begin{tabular}{|c|c|c|c|c|c|c|}
\hline \multirow{2}{*}{$\begin{array}{l}\text { HBeAg status } \\
\text { Age-group (years) }\end{array}$} & \multirow[t]{2}{*}{$n$} & \multicolumn{5}{|l|}{ Outcome } \\
\hline & & Cirrhosis (\%) & $\begin{array}{l}\text { Decompensated } \\
\text { Cirrhosis }(\%)\end{array}$ & $\mathrm{HCC}(\%)$ & Liver transplant (\%) & Death $(\%)$ \\
\hline \multicolumn{7}{|l|}{$\mathrm{HBeAg}+$} \\
\hline$<15$ & 90,621 & 819 (1) & $863(1)$ & $1,234(1)$ & $503(0,5)$ & $2,574(3)$ \\
\hline $15-24$ & 91,504 & $833(1)$ & 877 (1) & $1,257(1)$ & $512(0,5)$ & $2,617(3)$ \\
\hline $25-34$ & 113,892 & $35,401(31)$ & $12,082(11)$ & $8,461(7)$ & $5,776(5)$ & $27,276(24)$ \\
\hline $35-44$ & 35,222 & $10,966(31)$ & $3,694(11)$ & $2,561(7)$ & $1,769(5)$ & $8,316(24)$ \\
\hline $45-54$ & 11,923 & $3,783(32)$ & $1,741(15)$ & $1,050(9)$ & $825(7)$ & $3,842(32)$ \\
\hline $55-64$ & 5,070 & $1,630(32)$ & 779 (16) & $452(9)$ & $359(7)$ & $1,689(33)$ \\
\hline $65+$ & 4,565 & $1,574(34)$ & $241(5)$ & $206(5)$ & $109(2)$ & $526(12)$ \\
\hline All HBeAg+ & 352,797 & $55,006(16)$ & $20,277(6)$ & $15,221(4)$ & $9,853(3)$ & $46,840(13)$ \\
\hline \multicolumn{7}{|l|}{$\mathrm{HBeAg}-$} \\
\hline$<15$ & 47,586 & $424(1)$ & $680(1)$ & $1,153(2)$ & $412(1)$ & $2,465(5)$ \\
\hline $15-24$ & 45,804 & $406(1)$ & $657(1)$ & $1,110(2)$ & $400(1)$ & $2,389(5)$ \\
\hline $25-34$ & 132,322 & $99,242(75)$ & $22,392(17)$ & $26,464(20)$ & $11,770(9)$ & $67,484(51)$ \\
\hline $35-44$ & 96,610 & $73,924(76)$ & $16,424(17)$ & $19,322(20)$ & $8,695(9)$ & $50,237(52)$ \\
\hline $45-54$ & 74,353 & $54,278(73)$ & $12,640(17)$ & $15,614(21)$ & $6,692(9)$ & $39,407(53)$ \\
\hline $55-64$ & 41,595 & $28,285(68)$ & 7,071 (17) & 8,319 (20) & $3,744(9)$ & $22,045(53)$ \\
\hline $65+$ & 37,280 & $25,723(69)$ & $4,846(13)$ & $5,592(15)$ & $2,237(6)$ & $13,794(37)$ \\
\hline All HBeAg- & 475,550 & $323,374(68)$ & 76,088 (16) & 90,355 (19) & $38,044(8)$ & 223,509 (47) \\
\hline Total & 828,347 & 356,189 (43) & $91,118(11)$ & $99,402(12)$ & $49,701(6)$ & $256,788(31)$ \\
\hline
\end{tabular}

will need liver transplantation. At the entry into the cohort in the year 2009, 108,928 (13\%) cases were estimated to be already in the cirrhotic stage. By the year 2029, another $247,261(30 \%)$ cases will have developed cirrhosis if left untreated, and this will have led to a cumulative number of $356,189(43 \%)$ patients with cirrhosis in the eligible cohort.

Impact of antiviral treatment on burden of disease

Treating the cohort with lamivudine monotherapy will decrease the mortality from 256,787 (31\%) to 124,253 $(15 \%)$ of cases, and when salvage therapy without delay is applied once patients become resistant to lamivudine, mortality will further decrease to 49,700 (6\%) cases. With the Peg-IFN (followed by tenofovir) strategy mortality will be reduced to $82,834(10 \%)$ cases. Treating the same patients with entecavir or tenefovir monotherapy will decrease the mortality to 41,417 liver related deaths (5\%).

Cost-effectiveness

A plot of the outcomes of the various strategies on the costeffectiveness plane according to $\mathrm{HBeAg}$ and disease status is shown in Fig. 1. The total costs, QALYs gained, incremental QALYs, incremental costs and ICERs for each scenario are presented in Table 6.

\section{Chronic hepatitis (non-cirrhosis)}

The increasing health gain achieved over a period of 20 years for both $\mathrm{HBeAg}$-positive and -negative patients has been assessed for lamivudine, the roadmap concept (for HBeAg-negative only), adefovir salvage, tenofovir salvage, pegylated interferon (followed by tenofovir), entecavir and tenofovir therapy strategies.

The natural history (no-treatment) strategy resulted in 14 and 9.3 QALYs and total discounted 20-year CHB related healthcare costs of 25,781 TL $(€ 12,826)$ and 48,198 TL $(€ 23,979)$ for the HBeAg-positive and negative cohort, respectively.

Both tenofovir and entecavir had equal incremental QALYs; however, entecavir compared to tenofovir, in a 20 year follow up period was 11,252 TL $(€ 5,598)$ and $52,159 \mathrm{TL}(€ 25,949)$ more expensive in $\mathrm{HBeAg}$-positive and negative patients, respectively. The incremental costeffectiveness ratio (ICER) of tenofovir versus no treatment was $638 \mathrm{TL}(€ 318)$ and 15,573 TL $(€ 7,747)$ for HBeAgpositive and negative patients, respectively.

\section{CHB (cirrhosis)}

The no-treatment strategy resulted in 6.2 QALYs and total healthcare costs of $104,859 \mathrm{TL}(€ 52,168)$ and $93,954 \mathrm{TL}$ $(€ 46,743)$ for the cirrhotic HBeAg-positive and negative 

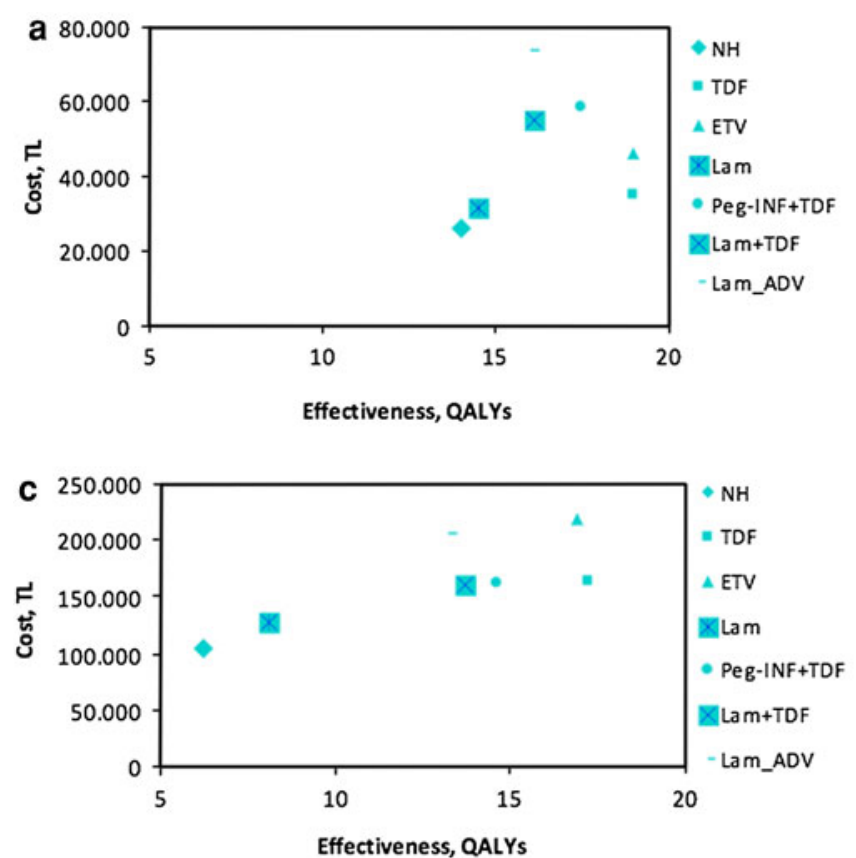

Fig. 1 Results of cost-effectiveness analysis stratified by hepatitis B e antigen ( $\mathrm{HBeAg}$ ) and stage of liver disease: a $\mathrm{HBeAg}$-positive (non-cirrhosis) b $\mathrm{HBeAg}$-negative (non-cirrhosis) c $\mathrm{HBeAg}$-positive (cirrhosis) d HBeAg-negative (cirrhosis). Results plotted on a costeffectiveness plane. The $x$-axis represents the gain in QALYs with

cohort, respectively. The lowest ICER was achieved with the tenofovir scenario versus no treatment which was 5,328 TL $(€ 2,650)$ and 6,609 TL $(€ 3,288)$ in the HBeAg-positive and negative cohort, respectively.

Sensitivity analysis

The sensitivity analysis for the natural history scenario shows that, in comparison with the base case, in which the mortality of the active CHB cohort is $31 \%$, the mortality ranges from $17 \%$ in the best case scenario to $42 \%$ in the worst case scenario. When assessed by subgroups, in the worst case scenario, mortality ranges from 4 to $28 \%$ for HBeAg-positive chronic hepatitis, from 8 to $35 \%$ for HBeAg-negative chronic hepatitis, and from 62 to $91 \%$ for cirrhosis independent of $\mathrm{HBeAg}$ status.

The ICER outcomes analysed when antiviral therapy were continued irrespective of $\mathrm{HBeAg}$-seroconversion, varied according to the therapy chosen. Tenofovir and entecavir monotherapy had an ICER of 22,100 TL $(€ 11,000)$ and $36,800 \mathrm{TL}(€ 18,000)$, respectively. The ICER for lamivudine monotherapy, lamivudine/adefovir salvage and lamivudine/tenofovir salvage were, 56,200 TL $(€ 27,900), 51,200 \mathrm{TL}(€ 25,400)$ and 26,200 TL (€13,000), respectively. Pegylated interferon (followed by tenofovir) had an ICER of 27,600 TL (€13,700).
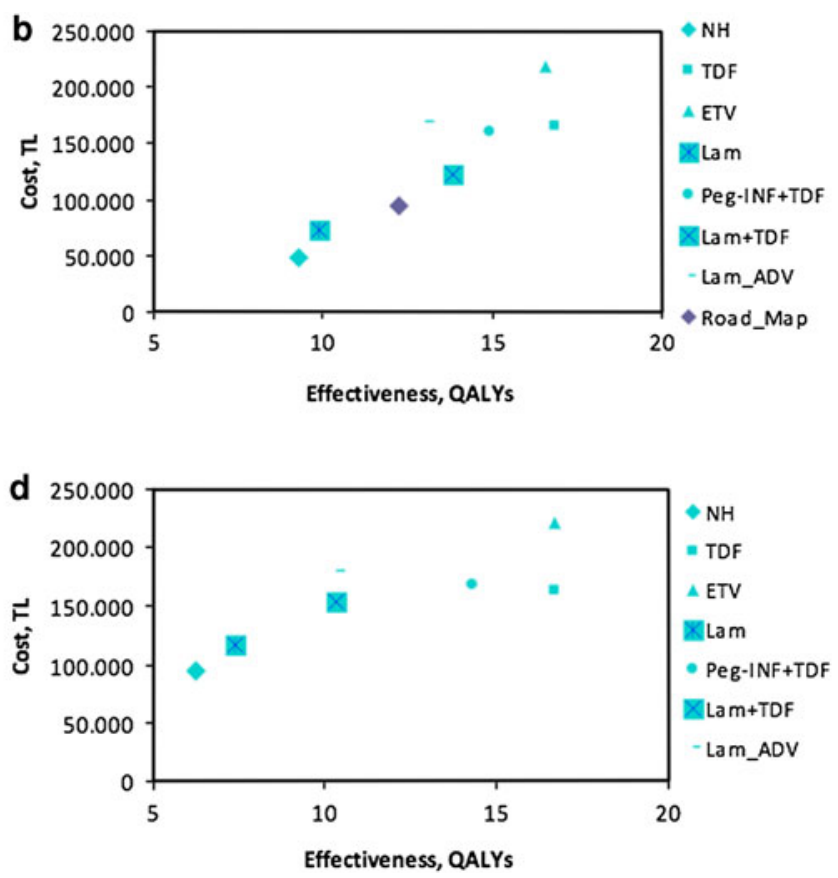

each strategy, and the $y$-axis the total healthcare costs (year 2010 values). $N H$ natural history, Lam lamivudine, $L a m+A D V$ adefovir salvage therapy, Peg_IFN $+T D F$ pegylated interferon followed by tenofovir, ETV entecavir, TDF tenofovir

The World Health Organization defines the threshold value for intervention cost-effectiveness as three times the gross national income (GNI) of a country. The threshold value for Turkey is 47,280 TL (€20,124) [49]. The probabilistic sensitivity analysis indicated that the no-treatment strategy was preferred at cost-effectiveness thresholds less than approximately $30,000 \mathrm{TL}(€ 14,925)$ per QALY, and tenofovir had the highest probability of being optimal above this threshold (Fig. 2) for the HBeAg-positive (noncirrhosis) patients. For the HBeAg-negative (non-cirrhosis) patients, tenofovir had the highest probability of being optimal above $30,000 \mathrm{TL}(€ 14,925)$ per QALY.

For the HBeAg-positive cirrhotic patients, at a 15,000 TL $(€ 7,462)$ per QALY threshold, tenofovir had the greatest net health benefit in $34 \%$ of the simulations, and pegylated Interferon (followed by tenofovir) in $10 \%$ of the

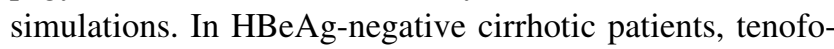
vir had a net health benefit of $46 \%$ and pegylated interferon (followed by tenofovir) $14 \%$ at a $15,000 \mathrm{TL}(€ 7,462)$ per QALY threshold.

Program costs for treating eligible patients

In addition to the cost and QALY gained per patient, we calculated the total program costs if the active CHB patients are identified and treated with the most cost- 
Table 6 Base case results of various scenarios: costs, quality adjusted life years (QALYs) gained, incremental QALYs, incremental costs and incremental cost-effectiveness ratios (ICERs)

\begin{tabular}{|c|c|c|c|c|c|c|c|c|}
\hline \multirow{2}{*}{$\begin{array}{l}\text { Treatment } \\
\text { HBeAg status }\end{array}$} & \multicolumn{2}{|l|}{$\mathrm{NH}^{*}$} & \multicolumn{2}{|l|}{ Lam } & \multicolumn{2}{|l|}{$\mathrm{Lam}+\mathrm{ADV}$} & \multicolumn{2}{|l|}{$\mathrm{Lam}+\mathrm{TDF}$} \\
\hline & + & - & + & - & + & - & + & - \\
\hline \multicolumn{9}{|l|}{ CHB (no cirrhosis) } \\
\hline $\begin{array}{l}\text { Cumulative costs } \\
(\times 1,000 \text { TL }(€))\end{array}$ & $25.7(12.8)$ & $48.2(23.9)$ & $31.6(15.7)$ & $72.6(36.1)$ & $73.4(36.5)$ & $168.5(83.8)$ & $54.7(27.2)$ & $122.5(60.9)$ \\
\hline Cumulative QALYs & 14.0 & 9.3 & 14.5 & 9.9 & 17.0 & 13.0 & 17.5 & 13.8 \\
\hline $\begin{array}{l}\text { Incremental costs } \\
(\times 1,000 \mathrm{TL}(€))^{\mathrm{a}}\end{array}$ & - & - & $5.8(2.9)$ & $24.4(12.1)$ & $41.9(20.8)$ & $120.3(59.9)$ & $23.2(11.5)$ & $74.4(37.0)$ \\
\hline Incremental QALYs ${ }^{\mathrm{b}}$ & - & - & 0.5 & 0.6 & 3.0 & 3.7 & 3.5 & 4.5 \\
\hline $\begin{array}{l}\text { ICER }(\times 1,000 \mathrm{TL} \\
(€) / \mathrm{QALY})\end{array}$ & - & - & $11.2(5.5)$ & $38.3(19.0)$ & $13.9(6.9)$ & $32.1(16.0)$ & $6.6(3.2)$ & $16.3(8.1)$ \\
\hline \multicolumn{9}{|l|}{ Cirrhosis } \\
\hline $\begin{array}{l}\text { Cumulative costs } \\
(\times 1,000 \mathrm{TL}(€))\end{array}$ & $104.9(52.2)$ & $93.9(46.7)$ & $128.1(63.7)$ & $117.2(20.1)$ & $205.5(102.2)$ & $180.0(89.6)$ & $160.6(79.9)$ & $154.6(76.9)$ \\
\hline Cumulative QALYs & 6.2 & 6.2 & 8.1 & 7.4 & 13.2 & 12.9 & 13.7 & 13.5 \\
\hline $\begin{array}{l}\text { Incremental costs } \\
(\times 1,000 \text { TL }(€))^{\mathrm{a}}\end{array}$ & - & - & $23.3(11.6)$ & $23.2(11.6)$ & $100.7(50.0)$ & $86.1(42.8)$ & $55.8(27.5)$ & $60.6(30.1)$ \\
\hline Incremental QALYs ${ }^{\mathrm{b}}$ & - & - & 1.9 & 1.2 & 7 & 6.7 & 7.5 & 7.3 \\
\hline $\begin{array}{l}\text { ICER }(\times 1,000 \text { TL } \\
(€) / \text { QALY })\end{array}$ & - & - & $12.5(6.2)$ & $20.1(10.0)$ & $14.5(7.2)$ & $12.9(6.4)$ & $7.5(3.7)$ & $8.3(4.1)$ \\
\hline \multicolumn{2}{|l|}{ Treatment } & \multicolumn{2}{|c|}{ Peg INF + TDF } & \multicolumn{2}{|l|}{ ETV } & \multicolumn{2}{|l|}{ TDF } & Roadmap \\
\hline $\mathrm{HBeAg}$ status & & + & - & + & - & + & - & - \\
\hline \multicolumn{9}{|l|}{ CHB (no cirrhosis) } \\
\hline \multicolumn{2}{|c|}{ Cumulative costs $(\times 1,000$ TL $(€))$} & $58.7(29.2)$ & $161.0(80.1)$ & $46.0(22.9)$ & $218.0(108.5)$ & $34.8(17.3)$ & $165.9(82.5)$ & $94.8(47.1)$ \\
\hline \multicolumn{2}{|c|}{ Cumulative QALYs } & 17.5 & 14.9 & 18.8 & 16.6 & 19.0 & 16.8 & 12.2 \\
\hline \multicolumn{2}{|c|}{ Incremental costs $(\times 1,000 \mathrm{TL}(€))^{\mathrm{a}}$} & $27.1(13.5)$ & $112.9(56.2)$ & $14.4(7.2)$ & $169.9(84.5)$ & $3.2(1.6)$ & $117.7(58.5)$ & $46.6(23.2)$ \\
\hline \multicolumn{2}{|l|}{ Incremental QALYs ${ }^{\mathrm{b}}$} & 3.5 & 5.6 & 4.8 & 7.3 & 5.0 & 7.6 & 2.9 \\
\hline \multicolumn{2}{|c|}{ ICER $(\times 1,000 \mathrm{TL}(€) / \mathrm{QALY})$} & $7.8(3.9)$ & $20.0(9.9)$ & $3.0(1.5)$ & $23.2(11.6)$ & $0.6(0.3)$ & $15.6(7.8)$ & $15.6(7.9)$ \\
\hline \multicolumn{9}{|l|}{ Cirrhosis } \\
\hline \multicolumn{2}{|c|}{ Cumulative costs $(\times 1,000$ TL $(€))$} & $162.9(81.0)$ & $168.2(83.7)$ & $218.5(108.7)$ & $220.8(109.8)$ & $163.5(81.3)$ & $163.1(81.2)$ & - \\
\hline \multicolumn{2}{|c|}{ Cumulative QALYs } & 14.6 & 14.3 & 16.9 & 16.5 & 17.2 & 16.7 & - \\
\hline \multicolumn{2}{|c|}{ Incremental costs $(\times 1,000 \mathrm{TL}(€))^{\mathrm{a}}$} & $58.1(28.9)$ & $74.2(36.9)$ & $113.6(56.5)$ & $126.8(63.1)$ & $58.6(29.2)$ & $69.1(34.4)$ & - \\
\hline \multicolumn{2}{|c|}{ Incremental QALYs ${ }^{\mathrm{b}}$} & 8.4 & 8.0 & 10.7 & 10.3 & 11.0 & 10.5 & - \\
\hline \multicolumn{2}{|c|}{ ICER $(\times 1,000 \mathrm{TL}(€) / \mathrm{QALY})$} & $6.9(3.4)$ & $9.2(4.6)$ & $10.7(5.3)$ & $12.3(6.1)$ & $5.3(2.6)$ & $6.6(3.3)$ & - \\
\hline
\end{tabular}

NH natural history, Lam lamivudine, Lam + ADV adefovir salvage therapy, Peg_IFN + TDF pegylated interferon followed by tenofovir, ETV entecavir, $T D F$ tenofovir

* "NH (no treatment)" was the baseline strategy compared with other treatment strategies

a Difference in costs over $\mathrm{NH}$

${ }^{\mathrm{b}}$ Difference in healthy years over $\mathrm{NH}$

effective strategy. Tenofovir monotherapy had the lowest ICER for all sub-groups (HBeAg-positive; $638 \mathrm{TL}$ ( $€ 318$ ), HBeAg-negative; 15,573 TL (€7,747), HBeAg-positive cirrhosis; 5,328 TL, (€2,650), HBeAg-negative cirrhosis; $6,609 \mathrm{TL},(€ 3,288))$, with ICERs far below the 36,212 TL $(€ 18,016)$ threshold value. If the total 828,347 active CHB patients (Table 5) are treated, it will cost about 4.6 billion TL ( $€ 2.3$ billion) annually, if not treated the total costs are tripled due to progression to liver failure and the high costs of medical treatment (hospitalization) and the need for liver transplantation.

\section{Discussion}

In a country where the estimated number of HBsAg-positive cases is more than 3.2 million, the total amount of treatment eligible patients, which was quantified through 

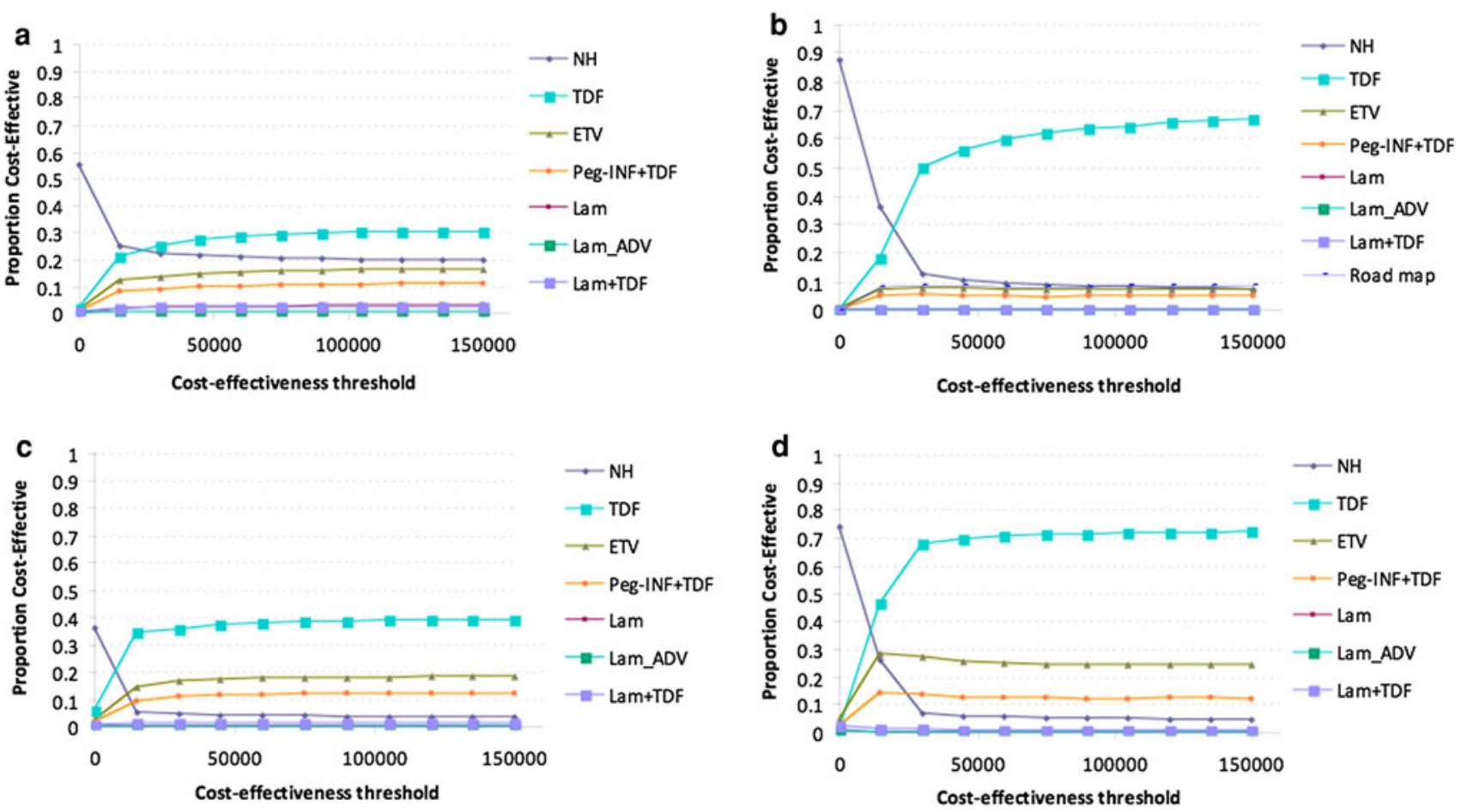

Fig. 2 Cost-effectiveness acceptability curves showing the probabilities of net benefits achieved by each strategy for different willingness to pay thresholds (the maximum amount a person is willing to pay for a good) in $\mathrm{HBeAg}$-positive (non-cirrhosis) (a), HBeAg-negative (noncirrhosis) (b), HBeAg-positive (cirrhosis) (c), and HBeAg-negative (cirrhosis) (d). The vertical axes represent the probability of cost-

population data and the large patient database constructed for this study, is 828,000, and of these, around 108,000 are patients with liver cirrhosis. If these eligible patients are not identified and treated, about 12,800 deaths are expected to occur each year due to liver related complications, leading to a cumulative number of 256,788 (31\%) in 20 years. The number of liver transplant patients in Turkey is $400-500$ per year and this treatment is covered by the health insurance [50]. If we would modestly assume that $50 \%$ of liver transplantations are due to $\mathrm{HBV}$, there will be a total of about 4,000 liver transplantations that will take place in 20 years, while the demand will be around 49,000, according to our estimates. On top of all the life years lost, and more severe treatment options such as liver transplantation are needed, the 20-year cumulative medical management cost of an untreated active $\mathrm{HBeAg}$-positive and HBeAg-negative CHB (no-cirrhosis) patient will be 25,781 TL (€12,800), and 48,198 TL (€23,900), respectively.

If the estimated active CHB cohort is identified and treated with the most cost-effective drug, liver related mortality and morbidity can be reduced by almost $80 \%$. Comparing treatment scenarios to the no antiviral treatment scenario in all the sub-cohorts, the tenofovir strategy was the most cost-effective. The ICER for HBeAg-

effectiveness. The horizontal axes represent willingness-to-pay threshold to gain one additional quality adjusted life year (QALY). $N H$ natural history, Lam lamivudine, Lam $+A D V$ adefovir salvage therapy, Peg_IFN + TDF pegylated interferon followed by tenofovir, ETV entecavir, $T D F$ tenofovir

positive and negative $\mathrm{CHB}$ (non-cirrhosis), and $\mathrm{HBeAg}$ positive and negative cirrhosis was $638 \mathrm{TL}$ ( $€ 306), 15,573$ TL (€7,800), 5,300 TL (€2,600), and 6,609 TL (€3,300), respectively. Both entecavir and tenofovir, compared to the do nothing scenario, had the same amount of health gain. A recent systematic review and Bayesian metaanalysis concludes that in the first year of treatment for $\mathrm{CHB}$, tenofovir and entecavir are the most potent oral antiviral agents for $\mathrm{HBeAg}$-positive patients, while for HBeAg-negative patients tenofovir is most effective [51]. According to net sold medication counts per year in Turkey, it was calculated that no more than $10 \%$ of active CHB patients receive antiviral treatment [52], indicating a massive shortcoming in providing eligible patients with life prolonged and even life saving treatments. At individual level the association of disease progression with increased cost of disease management suggests that measures to prevent or delay progression of CHB related liver diseases will be economically beneficial. At population level, however, the impact of therapy on the overall number of people with chronic infection will remain limited as long as the majority of infected patients will not receive treatment due to lack of recourse for optimal treatment. 
The future public health burden of chronic hepatitis $\mathrm{B}$ could potentially be reduced by antiviral treatment [53]. The recommendations by the Turkish Association for the Study of the Liver (TASL) [52] to treat eligible patients are in line with the European Association for the Study of the Liver [2] criteria, except that liver biopsy evidence is always required to start treatment in patients with no established cirrhosis. Almost all patients are reimbursed for treatment of viral hepatitis through the national insurance system in Turkey. A new modification issued in 2009 by the department within Turkish Health Authorities responsible for reimbursement decisions, states that lamivudine should be the first line therapy in all patients with viral load lower than $10^{7}$ copies $/ \mathrm{mL}$. This is largely due to the low costs of lamivudine and to the recent data about on-treatment monitoring approach, using serum HBV DNA level as a predictor for efficacy and drug resistance. We assessed whether this scenario (roadmap concept) was cost-effective in an $\mathrm{HBeAg}$-negative non-cirrhotic patients group, since sufficient data were available for this sub-group. The ICERs of both scenarios, roadmap concept $[15,829 \mathrm{TL}$ $(€ 7,875)]$ and tenofovir monotherapy [15,573 TL $(€ 7,747)]$, were equal. Although eight healthy life years were gained by tenofovir monotherapy while this was only three healthy life years gained for the roadmap concept scenario.

According to our outcomes, the roadmap concept could be an alternative strategy to consider for a country with a large $\mathrm{HBeAg}$-negative disease, where tenofovir is not available. This scenario could also be suggested in resource poor settings, since the cumulative costs to treat are less compared to tenofovir monotherapy. Various studies have examined the cost-effectiveness of antiviral therapy for $\mathrm{CHB}$ and have concluded that treatment is cost-effective versus no treatment [10, 15, 54-56]. Kanwal et al. [10] found that lamivudine monotherapy strategy was more expensive and less effective than treatment with interferon or salvaged by adefovir. According to our analysis, lamivudine monotherapy was less effective as well, but was not more expensive compared to other treatment strategies. This can be explained by the fact that more than 5 years have elapsed between both studies during which the price of lamivudine has decreased. Buti et al. [57] concludes that first-line treatment with tenofovir is cost-effective for both HBeAg-positive and negative patients, in comparison to other antivirals. They also conclude that tenofovir was more effective than entecavir, which is in contrast to our results for which the efficacy equality was equal for both drugs.

A country with similar patient characteristics and health care system may benefit from our scenario analysis and outcomes related to the burden of disease. Considering the economic affordability in different countries, the cost- effectiveness thresholds may be different. It may be that in a country where the threshold is high, a more expensive but effective drug is cost-effective, while this might not be the case for this same drug in a country with a lower costeffectiveness threshold. A review study by Barbieri et al. [58] on the generalizability of cost-effectiveness studies concludes that the differences in cost-effectiveness results between countries are not systematic, which makes inferences from one country to another difficult.

A limitation of our study is that we used simplified assumptions (e.g., we did not consider coinfection with other viruses or toxins such as alcohol that will accelerate progression), and we assumed the cohort to be static, so there were no new cases added to the cohort. Also, the assumption that the development of resistance both with entecavir and tenofovir for the coming 20 years will stay at 0-1 \% per year may underestimate what will happen as longer term data are collected. We took a rather conservative approach by only including high HBV DNA and ALT $>2 \times$ ULN. If, like in the guidelines, we had taken elevated ALT levels but starting at $1 \times \mathrm{ULN}$, the number of eligible patients would have increased. Another factor that surely plays an important role in the estimation of eligible patients is the inclusion of data from tertiary centres. In Turkey, data on viral hepatitis are collected at the provincial health directorate, but only for acute (incident) cases. Thus, the data on CHB patients is derived from clinical settings, of which not all patients coming to the hospital have active disease. Some patients are detected during the diagnostic process for other diseases and referred to the hepatology department. We conclude that the cohort data from Turkey are, therefore, likely to be biased towards more active $\mathrm{CHB}$ cases, which could mean that the number of eligible patients might be an overestimation. One way to account for this bias would be to implement new information systems and registries to facilitate the notification, counseling, and medical management of persons with $\mathrm{CHB}$ infections in countries with intermediate or high endemicity. Any attempt to predict the future is likely to be biased. Therefore, our projections and estimates regarding future treatment rates and liver-related deaths are only intended to provide a crude overview of the public health impact of antiviral therapy.

Identification of chronic hepatitis B infected individuals is essential to ensure that infected persons receive necessary care to prevent or delay onset of significant liver disease and services to prevent transmission to others. Achieving identification could be done by monitoring inactive cases annually, as is recommended in the guidelines. Antenatal screening should be routinely performs, and new information systems and registries should be implemented to facilitate the notification, counselling, and medical management of persons with chronic HBV 
infection in countries with intermediate and high endemicity. Given the substantial mortality and morbidity attributable to $\mathrm{HBV}$ related chronic liver diseases, the control of progression to cirrhosis, decompensated cirrhosis and liver cancer will continue to be an important public health priority. Third generation drugs, such as entecavir and tenofovir, with high effectiveness and low resistance profiles, should be made more affordable to help people with active chronic hepatitis B lead healthier lives.

Acknowledgments The authors would like to thank the following people from various liver transplantation centres for their contribution of information: Dr. Dinc Dincer of Antalya Medical Faculty, Dr. Murat Danyangac of Istanbul Florence Nightingale hospital, Meral Kose of Ibn-i Sina hospital, Ankara, Dr. Sebahattin Kaymakoglu of Istanbul Medical Faculty, Dr. Zeki Karasu of Ege University, Izmir, Dr. Yilmaz Cakaloglu of Istanbul Memorial hospital.

Conflict of interest This study was supported by the European Association for the study of the liver (EASL). Dame Sheila Sherlock short-term fellowship awarded to Mehlika Toy.

Open Access This article is distributed under the terms of the Creative Commons Attribution License which permits any use, distribution, and reproduction in any medium, provided the original author(s) and the source are credited.

\section{References}

1. Lavanchy, D.: Hepatitis B virus epidemiology, disease burden, treatment, and current and emerging prevention and control measures. J. Viral Hepat. 11(2), 97-107 (2004)

2. European Association For The Study of The Liver: EASL clinical practice guidelines: management of chronic hepatitis B. J. Hepatol. 50(2), 227-242 (2009)

3. Lok, A.S., McMahon, B.J.: Chronic hepatitis B: update 2009. Hepatology 50, 661-662 (2009)

4. Ferenci, P., Fried, M., Labrecque, D., Bruix, J., Sherman, M., Omata, M., Heathcote, J., Piratsivuth, T., Kew, M., Otegbayo, J.A., Zheng, S.S., Sarin, S., Hamid, S.S., Modawi, S.B., Fleig, W., Fedail, S., Thomson, A., Khan, A., Malfertheiner, P., Lau, G., Carillo, F.J., Krabshuis, J., Le Mair, A.: World Gastroenterology O: Hepatocellular carcinoma (HCC): a global perspective. J. Clin. Gastroenterol. 44(4), 239-245 (2010). doi:10.1097/MCG.0b013 e3181d46ef2

5. Yurdaydin, C., Akarca, U.: Treatment of chronic hepatitis B with telbuvidine: wise hepatologists needed in hepatitis B endemic countries where treatment options are limited. Liver Int. 31(5), 589-591 (2011)

6. Toy, M., Onder, F.O., Wormann, T., Bozdayi, M., Schalm, S.W., Borsboom, G.J., Idilman, R., Richardus, J.H., Yurdaydin, C.: Age- and region-specific hepatitis B prevalence in Turkey estimated using generalized linear mixed models: a systematic review. BioMed Central Infect. Dis. 11, 337 (2011)

7. Turkish Statistics Institute: In., p. http://www.tuik.gov.tr/Start.do. (2010)

8. Hadziyannis, S.J., Tassopoulos, N.C., Heathcote, E.J., Chang, T.T., Kitis, G., Rizzetto, M., Marcellin, P., Lim, S.G., Goodman, Z., Wulfsohn, M.S., Xiong, S., Fry, J., Brosgart, C.L.: Adefovir dipivoxil for the treatment of hepatitis $\mathrm{B}$ e antigen-negative chronic hepatitis B. N. Engl. J. Med. 348(9), 800-807 (2003)

9. Janssen, H.L., van Zonneveld, M., Senturk, H., Zeuzem, S., Akarca, U.S., Cakaloglu, Y., Simon, C., So, T.M., Gerken, G., de Man, R.A., Niesters, H.G., Zondervan, P., Hansen, B., Schalm, S.W.: Pegylated interferon alfa- $2 b$ alone or in combination with lamivudine for $\mathrm{HBeAg}$-positive chronic hepatitis $\mathrm{B}$ : a randomised trial. Lancet 365(9454), 123-129 (2005)

10. Kanwal, F., Gralnek, I.M., Martin, P., Dulai, G.S., Farid, M., Spiegel, B.M.: Treatment alternatives for chronic hepatitis B virus infection: a cost-effectiveness analysis. Ann. Intern. Med. 142(10), 821-831 (2005)

11. Fattovich, G., Bortolotti, F., Donato, F.: Natural history of chronic hepatitis B: special emphasis on disease progression and prognostic factors. J. Hepatol. 48, 335-352 (2008)

12. Fattovich, G., Pantalena, M., Zagni, I., Realdi, G., Schalm, S.W., Christensen, E.: Effect of hepatitis B and C virus infections on the natural history of compensated cirrhosis: a cohort study of 297 patients. Am. J. Gastroenterol. 97(11), 2886-2895 (2002)

13. Fattovich, G., Giustina, G., Schalm, S.W., Hadziyannis, S., Sanchez-Tapias, J., Almasio, P., Christensen, E., Krogsgaard, K., Degos, F., Carneiro de Moura, M., et al.: Occurrence of hepatocellular carcinoma and decompensation in western European patients with cirrhosis type B. The EUROHEP Study Group on Hepatitis B Virus and Cirrhosis. Hepatology 21(1), 77-82 (1995)

14. Realdi, G., Fattovich, G., Hadziyannis, S., Schalm, S.W., Almasio, P., Sanchez-Tapias, J., Christensen, E., Giustina, G., Noventa, F.: Survival and prognostic factors in 366 patients with compensated cirrhosis type B: a multicenter study. The Investigators of the European Concerted Action on Viral Hepatitis (EUROHEP). J. Hepatol. 21(4), 656-666 (1994)

15. Kanwal, F., Farid, M., Martin, P., Chen, G., Gralnek, I.M., Dulai, G.S., Spiegel, B.M.: Treatment alternatives for hepatitis B cirrhosis: a cost-effectiveness analysis. Am. J. Gastroenterol. 101(9), 2076-2089 (2006)

16. Chang, T.T., Gish, R.G., de Man, R., Gadano, A., Sollano, J., Chao, Y.C., Lok, A.S., Han, K.H., Goodman, Z., Zhu, J., Cross, A., DeHertogh, D., Wilber, R., Colonno, R., Apelian, D.: A comparison of entecavir and lamivudine for $\mathrm{HBeAg}$-positive chronic hepatitis B. N. Engl. J. Med. 354(10), 1001-1010 (2006)

17. Lai, C.L., Shouval, D., Lok, A.S., Chang, T.T., Cheinquer, H., Goodman, Z., DeHertogh, D., Wilber, R., Zink, R.C., Cross, A., Colonno, R., Fernandes, L.: Entecavir versus lamivudine for patients with $\mathrm{HBeAg}$-negative chronic hepatitis B. N. Engl. J. Med. 354(10), 1011-1020 (2006)

18. Colonno, R.J., Rose, R.E., Pokornowski, K., Baldick, C.J., Eggers, B., Xu, D., Cross, A., Tenney, D.J.: Four year assessment of entecavir resistance in nucleoside naïve and lamivudine refractory patients. J. Hepatol. 46(Suppl. 1), S294 (2007)

19. Lai, C.L., Dienstag, J., Schiff, E., Leung, N.W., Atkins, M., Hunt, C., Brown, N., Woessner, M., Boehme, R., Condreay, L.: Prevalence and clinical correlates of YMDD variants during lamivudine therapy for patients with chronic hepatitis B. Clin. Infect. Dis. 36(6), 687-696 (2003)

20. Moskovitz, D.N., Osiowy, C., Giles, E., Tomlinson, G., Heathcote, E.J.: Response to long-term lamivudine treatment (up to 5 years) in patients with severe chronic hepatitis B, role of genotype and drug resistance. J. Viral Hepat. 12(4), 398-404 (2005)

21. Lee, Y.S., Suh, D.J., Lim, Y.S., Jung, S.W., Kim, K.M., Lee, H.C., Chung, Y.H., Lee, Y.S., Yoo, W., Kim, S.O.: Increased risk of adefovir resistance in patients with lamivudine-resistant chronic hepatitis B after 48 weeks of adefovir dipivoxil monotherapy. Hepatology 43(6), 1385-1391 (2006)

22. Chen, C.H., Wang, J.H., Lee, C.M., Hung, C.H., Hu, T.H., Wang, J.C., Lu, S.N., Changchien, C.S.: Virological response and 
incidence of adefovir resistance in lamivudine-resistant patients treated with adefovir dipivoxil. Antivir. Ther. 11(6), 771-778 (2006)

23. Yeon, J.E., Yoo, W., Hong, S.P., Chang, Y.J., Yu, S.K., Kim, J.H., Seo, Y.S., Chung, H.J., Moon, M.S., Kim, S.O., Byun, K.S., Lee, C.H.: Resistance to adefovir dipivoxil in lamivudine resistant chronic hepatitis B patients treated with adefovir dipivoxil. Gut 55(10), 1488-1495 (2006)

24. Liaw, Y.F., Sung, J.J., Chow, W.C., Farrell, G., Lee, C.Z., Yuen, H., Tanwandee, T., Tao, Q.M., Shue, K., Keene, O.N., Dixon, J.S., Gray, D.F., Sabbat, J.: Lamivudine for patients with chronic hepatitis B and advanced liver disease. N. Engl. J. Med. 351(15), 1521-1531 (2004)

25. Colonno, R.J., Rose, R., Baldick, C.J., Levine, S., Pokornowski, K., Yu, C.F., Walsh, A., Fang, J., Hsu, M., Mazzucco, C., Eggers, B., Zhang, S., Plym, M., Klesczewski, K., Tenney, D.J.: Entecavir resistance is rare in nucleoside naive patients with hepatitis B. Hepatology 44(6), 1656-1665 (2006)

26. Tenney, D.J., Rose, R.E., Baldick, C.J., Pokornowski, K.A., Eggers, B.J., Fang, J., Wichroski, M.J., Xu, D., Yang, J., Wilber, R.B., Colonno, R.J.: Long-term monitoring shows hepatitis B virus resistance to entecavir in nucleoside-naive patients is rare through 5 years of therapy. Hepatology 49(5), 1503-1514 (2009)

27. Heathcote, E.J., Marcellin, P., Buti, M., Gane, E., De Man, R.A., Krastev, Z., Germanidis, G., Lee, S.S., Flisiak, R., Kaita, K., Manns, M., Kotzev, I., Tchernev, K., Buggisch, P., Weilert, F., Kurdas, O.O., Shiffman, M.L., Trinh, H., Gurel, S., Snow-Lampart, A., Borroto-Esoda, K., Mondou, E., Anderson, J., Sorbel, J., Rousseau, F.: Three-year efficacy and safety of tenofovir disoproxil fumarate treatment for chronic hepatitis B. Gastroenterology 140(1), 132-143 (2011). doi:10.1053/j.gastro.2010.10.011

28. van Bommel, F., Wunsche, T., Mauss, S., Reinke, P., Bergk, A., Schurmann, D., Wiedenmann, B., Berg, T.: Comparison of adefovir and tenofovir in the treatment of lamivudine-resistant hepatitis B virus infection. Hepatology 40(6), 1421-1425 (2004)

29. Sarin, N., Yim, C., Feld, J.J., Heathcote, E.J., Wong, D.K.: Tenofovir is effective salvage therapy for nucleoside-resistant hepatitis B. abstract nr: 454, AASLD 2009 Boston (2009)

30. Van Bommel, F., De Man, R., Ferenci, P., Reijnders, J.G., Bronowicki, J.P., Fulop, B., Wedemeyer, H., Erhardt, A., Hueppe, D., Bourliere, M., Sarrazin, C., Trojan, J., Buggisch, P., Petersen, J., Spenger, U., Brost, S., Pariente, A., Schuchmann, M., Wasmuth, H.E., Deterding, K., Rutter, K., Feucht, H.H., Wiedenmann, B., Berg, T.: Long-term follow-up evaluation of the efficacy and safety of tenofovir disoproxil fumarate (TDF) in a european multicenter (nucleos(t)ide experienced) hepatitis B virus HBV infected cohort. abstract nr: 221, AASLD 2009 Boston (2009)

31. Reijnders, J.G., Janssen, H.L.: Potency of tenofovir in chronic hepatitis B: mono or combination therapy? J. Hepatol. 48(3), 383-386 (2008)

32. Lau, G.K., Piratvisuth, T., Luo, K.X., Marcellin, P., Thongsawat, S., Cooksley, G., Gane, E., Fried, M.W., Chow, W.C., Paik, S.W., Chang, W.Y., Berg, T., Flisiak, R., McCloud, P., Pluck, N.: Peginterferon Alfa-2a, lamivudine, and the combination for HBeAg-positive chronic hepatitis B. N. Engl. J. Med. 352(26), 2682-2695 (2005)

33. Marcellin, P., Bonino, F., Lau, G.K., Farci, P., Yurdaydin, C., Piratvisuth, T., Jin, R., Gurel, S., Lu, Z.M., Wu, J., Popescu, M., Hadziyannis, S.: Sustained response of hepatitis B e antigennegative patients 3 years after treatment with peginterferon alpha-2a. Gastroenterology 136(7), 2169-2179 e2161-2164 (2009)

34. Cooksley, W.G., Piratvisuth, T., Lee, S.D., Mahachai, V., Chao, Y.C., Tanwandee, T., Chutaputti, A., Chang, W.Y., Zahm, F.E., Pluck, N.: Peginterferon alpha-2a (40 kDa): an advance in the treatment of hepatitis B e antigen-positive chronic hepatitis B. J. Viral Hepat. 10(4), 298-305 (2003)

35. Piratvisuth, T., Lau, G., Chao, Y.C., Jin, R., Chutaputti, A., Zhang, Q.B., Tanwandee, T., Button, P., Popescu, M.: Sustained response to peginterferon alfa-2a $(40 \mathrm{kD})$ with or without lamivudine in Asian patients with $\mathrm{HBeAg}$-positive and $\mathrm{HBeAg}$-negative chronic hepatitis B. Hepatol. Int. 2(1), 102-110 (2008)

36. Fleurence, R.L., Hollenbeak, C.S.: Rates and probabilities in economic modelling: transformation, translation and appropriate application. Pharmacoeconomics 25(1), 3-6 (2007)

37. Kennedy, P.T., Phillips, N., Chandrasekhar, J., Jacobs, R., Jacobs, M., Dusheiko, G.: Potential and limitations of lamivudine monotherapy in chronic hepatitis B: evidence from genotyping. Liver Int. 28(5), 699-704 (2008)

38. Shouval, D., Lai, C.L., Chang, T.T., Cheinquer, H., Martin, P., Carosi, G., Han, S., Kaymakoglu, S., Tamez, R., Yang, J., Tenney, D., Brett-Smith, H.: Relapse of hepatitis B in HBeAg-negative chronic hepatitis B patients who discontinued successful entecavir treatment: the case for continuous antiviral therapy. J. Hepatol. 50(2), 289-295 (2009)

39. Reijnders, J.G., Perquin, M.J., Zhang, N., Hansen, B.E., Janssen, H.L.: Nucleos(t)ide analogues only induce temporary hepatitis B e antigen seroconversion in most patients with chronic hepatitis B. Gastroenterology 139(2), 491-498 (2010)

40. Marcellin, P., Lau, G.K., Bonino, F., Farci, P., Hadziyannis, S., Jin, R., Lu, Z.M., Piratvisuth, T., Germanidis, G., Yurdaydin, C., Diago, M., Gurel, S., Lai, M.Y., Button, P., Pluck, N.: Peginterferon alfa-2a alone, lamivudine alone, and the two in combination in patients with $\mathrm{HBe} A g$-negative chronic hepatitis B. N. Engl. J. Med. 351(12), 1206-1217 (2004)

41. Keeffe, E.B., Zeuzem, S., Koff, R.S., Dieterich, D.T., EstebanMur, R., Gane, E.J., Jacobson, I.M., Lim, S.G., Naoumov, N., Marcellin, P., Piratvisuth, T., Zoulim, F.: Report of an international workshop: roadmap for management of patients receiving oral therapy for chronic hepatitis B. Clin. Gastroenterol. Hepatol. 5(8), 890-897 (2007). doi:10.1016/j.cgh.2007.05.004

42. Chang, T.T.: On-treatment monitoring of HBV DNA levels: predicting response and resistance to oral antiviral therapy at week 24 versus week 48. Hepatol. Int. 3(Suppl 1), 16-23 (2009)

43. Lai, C.L., Gane, E., Liaw, Y.F., Hsu, C.W., Thongsawat, S., Wang, Y., Chen, Y., Heathcote, E.J., Rasenack, J., Bzowej, N., Naoumov, N.V., Di Bisceglie, A.M., Zeuzem, S., Moon, Y.M., Goodman, Z., Chao, G., Constance, B.F., Brown, N.A.: Telbivudine versus lamivudine in patients with chronic hepatitis B. N. Engl. J. Med. 357(25), 2576-2588 (2007)

44. Hadziyannis, A.S., Mitsoula, P.V., Hadziyannis, S.J.: Prediction of long-term maintenance of virologic response during lamivudine treatment in $\mathrm{HBeAg}$-negative chronic hepatitis B. Hepatology 46(Suppl. 1), 667A (2007)

45. Turkish Health Ministry: Turkish Health Ministry Drugs and pharmaceutical head quarters. vol. 2009, December http://www. iegm.gov.tr/Default.aspx?sayfa=fiyat_listesi (2010)

46. Levy, A.R., Kowdley, K.V., Iloeje, U., Tafesse, E., Mukherjee, J., Gish, R., Bzowej, N., Briggs, A.H.: The impact of chronic hepatitis $\mathrm{B}$ on quality of life: a multinational study of utilities from infected and uninfected persons. Value Health 11(3), 527-538 (2008)

47. Gold, M.R., Siegel, J.E., Russel, L.B., Weinstein, M.G.: CostEffectiveness in Health and Medicine. Oxford University Press, New York (1996)

48. Drummond, M.F., Jefferson, T.O.: Guidelines for authors and peer reviewers of economic submissions to the BMJ the BMJ economic evaluation working party. BMJ 313(7052), 275-283 (1996)

49. World Health Organization: WHO guide to cost-effectiveness. In., p. http://www.who.int/choice/publications/p_2003_generalised cea.pdf (2003) 
50. Karasu, Z., Akyildiz, M., Kilic, M., Zeytunlu, M., Aydin, U., Tekin, F., Yilmaz, F., Ozacar, T., Akarca, U., Ersoz, G., Gunsar, F., Ilter, T., Lucey, M.R.: Living donor liver transplantation for hepatitis B cirrhosis. J. Gastroenterol. Hepatol. 22(12), 21242129 (2007). doi:10.1111/j.1440-1746.2006.04782.x

51. Woo, G., Tomlinson, G., Nishikawa, Y., Kowgier, M., Sherman, M., Wong, D.K., Pham, B., Ungar, W.J., Einarson, T.R., Heathcote, E.J., Krahn, M.: Tenofovir and entecavir are the most effective antiviral agents for chronic hepatitis B: a systematic review and bayesian meta-analyses. Gastroenterology 139(4), 1218-1229 e1215 (2010). doi:10.1053/j.gastro.2010.06.042

52. Akarca, U.S.: Chronic hepatitis B. A guideline to diagnosis, approach, management, and follow-up 2007. Turkish Association for the Study of Liver. Turk. J. Gastroenterol. 19(4), 207-230 (2008)

53. Toy, M., Veldhuijzen, I.K., de Man, R.A., Richardus, J.H., Schalm, S.W.: Potential impact of long-term nucleoside therapy on the mortality and morbidity of active chronic hepatitis B. Hepatology 50(3), 743-751 (2009)
54. Wong, J.B., Koff, R.S., Tine, F., Pauker, S.G.: Cost-effectiveness of interferon-alpha $2 b$ treatment for hepatitis $B$ e antigen-positive chronic hepatitis B. Ann. Intern. Med. 122(9), 664-675 (1995)

55. Spackman, D.E., Veenstra, D.L.: A cost-effectiveness analysis of currently approved treatments for $\mathrm{HBeAg}$-positive chronic hepatitis B. Pharmacoeconomics 26(11), 937-949 (2008)

56. Shepherd, J., Jones, J., Takeda, A., Davidson, P., Price, A.: Adefovir dipivoxil and pegylated interferon alfa-2a for the treatment of chronic hepatitis B: a systematic review and economic evaluation. Health Technol. Assess. 10(28), iii-iv, xi-xiv, 1-183 (2006)

57. Buti, M., Brosa, M., Casado, M.A., Rueda, M., Esteban, R.: Modeling the cost-effectiveness of different oral antiviral therapies in patients with chronic hepatitis B. J. Hepatol. 51(4), 640-646 (2009). doi:10.1016/j.jhep.2009.04.013

58. Barbieri, M., Drummond, M., Willke, R., Chancellor, J., Jolain, B., Towse, A.: Variability of cost-effectiveness estimates for pharmaceuticals in Western Europe: lessons for inferring generalizability. Value Health 8(1), 10-23 (2005) 